\title{
The Realization of Directive Speech Act by Da'i on Dialogic Da'wah in Kota Surakarta: A Socio-Pragmatic Study
}

Komunitas: International Journal of Indonesian Society and Culture 10(1) (2018): 14-24

DOI:10.15294/komunitas.v9i1.12930 (C) 2018 Semarang State University, Indonesia p-ISSN 2086 - 5465 | e-ISSN 2460-7320 http://journal.unnes.ac.id/nju/index.php/komunitas UNNDS JOURNALS

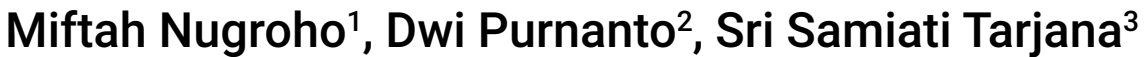

${ }^{1}$ Universitas Sebelas Maret of Surakarta

Received: 25 January 2018; Accepted: 1 March 2018; Published: 30 March 2018

\begin{abstract}
Abstract. This article aims at explaining the directive speech acts realization on Q\&A sessions of a dialogic situated communication. The directive speech requires a communicative counterpart (to do something as the speaker's wishes) by his/her words. Under the Sociopragmatic is the crossdisciple study between the pragmatic and sociological disciplines. The data were obtained by applying methods of observation and recording. The data source of this study took the Islamic liturgical dialogues dakwah held by both Islamic organizations and Islamic sermons held at schools, homes, or mosques. The result shows that, in terms of the communicative functions, the directive speech acts were realized from the acts of suggesting, and warning, a da'i or preachers are adhering to the principle of harmony as reflected from their commitment towards the observed maxims of kurmat, andhap asor and the tepa slilra.
\end{abstract}

\section{Keywords}

directive; speech acts; dai; preacher, the harmonious principle

\section{INTRODUCTION}

In everyday communication, a person not only says something that reflects information. In other words, a person's utterance also contains an action. This is in lined with Austin's opinion that a person instead of just producing a mere words, he/she is also performs actions. In that sense, producing an utterance that reflects certain action in pragmatic world of disciple is the so called speech acts (Yule, 1996). At the when a person producing a speech act, he/she should not say something haphazardly. A person who speaks or is called a speaker needs to pay attention to various factors before conveying his speech acts, such as how social relationships between the speakers and his/ her speaking counterpart, where the act of speech takes place, how are the speech acts use conditions (towards felicity) when certain utterances conveyed and produced (contextually bond), in addition to the aims for the produced acts of speech (which imply certain functions), and so forth.

In addition to the aforementioned factors, there are also other factors affecting communication, which is politeness consideration. The language politeness as suggested by Lakoff (cited in Fraser, 1990) which is "a device used in order to reduce friction in

\footnotetext{
Corresponding author

Karangduren RT04/IV, Jati, Jatem Karanganyar

Central Java, Indonesia

Email

miftahnugroho@gmail.com
} 
personal interaction". While, Brown and Levinson (1987) put forward an opion that that language politeness concerns strategy aimed at softening the face threatening-acts. Speaking of language politeness of course also it is highly adhered to the culture. A culture as was further explained by Žegarag (2008: 49) is "representation which are relatively stable and which form systems shared by the members of a social group are cultural. Therefore, culture distinguishes one social group from another". Having inspired by Žegarag's opinion, a culture concerns the adhering values brought by societies and each society have their own specific characteristics. This has been consequently affecting the linguistic politeness or the accepted communicative manners within society. In other words, a linguistic politeness of a certain community may be different from other communities as the differences in culture mark different typical use of politeness.

Thus, at a time of a speaker engages in a conversation, a person may not only produce words, however, only he/she implies intended acts. What a speaker needs to be aware of is that some speech acts are inherently face-threatening. The face as emphasized by Brown and Levinson (1987) is a selfinterpreted self-image of a rational person. Face is a personal part prone to some speech acts. Out of the existing various speech acts of verbal interaction between speakers, there are acts of threatening face, one of which is the directive act. The directive speech acts concern the act of demanding the speaking partners to do what the speaker say (Searle, 1979). Because of that, this speech is the uttering thing without necessarily threatening the speaking partners' face. Moreover, the realization of directive speech acts associated with culture. This certainly consequently generates a lot of effects on the delivered speech acts.

Language study can take various domains. One of the interesting areas to be studied is the use of language in the realm of dawah or Islamic liturgic discourse. In the realm of da'wah, especially dialogic one, there are found typical use of language by da'i 'preacher' and mad'u 'discourse recipi- ents. Related the language of $d a{ }^{\prime} i$, it is part of the important thing to effectively direct the messages to the addressee. In the speech event of da'wah, the dai is a doer who has greater authority than other speakers. Due to having a great authority, of course, the da'i especially directive speech act, without considering whether the speech may be threatening the speaking partners' face. The interesting thing to examine, is how the the directive speech act realization delivered by the dai, bearing an Islamically framed discoursed lecture delivered in the city of Surakarta. Surakarta city is known as one of the center of Javanese culture will definitely affect dai in delivering a lecture. In other words, whether the dai will fully consider the value of Javanese culture in expressing the directive speech act. For that reason, this paper uses a sociopragmatic approach. Sociopragmatics according to Leech (1983) is a pragmatic description associated with certain social conditions. Sociopragmatic is necessary in interacting because the use of language by society is influenced by cultural values. Whereas the cultural values of society with the cultural values of other communities vary. In short, this study involves the disciplines of sociology, anthropology, and pragmatics.

\section{Review of Related Literature}

Previous study results on linguistic politeness have much been focused on the lexical elements as emphasized in Locher's study (2004), and Riekenen (2009) as the lexeme which normally appear in the interactional communication in the academics environmental situation, and also Fortanent (2003) who successfully distinguish the function of phrase I think into three, which is the starting point for the study on the aspects of politeness tools Then, Murni (2009) focuses her study on politeness, sentence, pronoun, and phrase-level elements, and the latest one is Sosiowati's (2013) study which reveals the existence of ideological practice in politically polite language, she in further a general overview of the ideological elements realized through speech acts.

Based on more theoretical studies, 
several overviews and analyzes of critical and holistic politeness studies have been extensively described in several studies, for example by Eelen (2001), Watts (2003) and Bargiela-Chiappini (2003). Long before, Fraser (1990) postulated four parameters in understanding politeness, including; "social norms", "conversational maxims", "facesaving" and "conversation contracts" Eelen (2001) further asserts that the term politeness is not only seen as a strategy to avoid conflict, but also indicates the universal social position of its speakers Eelen (2001) was inspired by previous Kasper's study (1990) who found that politeness is operated as a strategy conflict avoidance, politeness has a social function as a way for speakers to control the potential of aggression in speech (Brown \& Levinson, 1987, p. 1), or avoid disturbance and maintain social equilibrium and communicative concord ( Leech, 1983, p 17-82). The idea of politeness as a social mirror of its speakers can be interpreted as appropriate and socially acceptable behavior and so far still depends on the social position of the communication. For example, a speech situation involving academics or intellectuals must generate new ideas about the nuances and models of language-based practice.

\section{METHOD}

This study is included into qualitative research. There are three reasons why this research is qualitative research. First, this study examines attitudes or behaviors in the environment of natural objects. The natural environment or object is "the object that develops as it is, is not manipulated by the researcher, and the researcher's presence does not affect dynamics of the object" (Sugiyono, 2011: 13). The environment or natural object in question is dialogic da'wah organized by Islamic mass organizations and non-organizations organized both at home and mosque. The dialogic da'wah or preaching held at these places is natural because there is no attempt to manipulate the use of language even though researchers present at the location. Secondly, as the Bogdan and
Taylor's opinion (cited in Moleong 2011, p. 4) this is classified into qualitative research since "the research procedure produced tangible descriptive data in the form of words written or spoken derived from people and observed behavior". In addition, this study is also classified as descriptive-qualitative research because the purpose of this study is to describe and describe in detail and depth about the use of language on dialogic $d a$ 'wah. This is in line with Sudaryanto's suggestion (1988: 62) that "the descriptive term offered a typical research conducted solely on the basis of existing facts or phenomena that are empirically alive to the speakers so that the resulting or recorded ordinary languages may be referred to as portraits or exposures as they are".

Meanwhile, this study took authentic oral data. The data is authentic since they were obtained naturally in a reasonable communication event (speech). The data concern the real results of the speech participants' dialogic communication, ie they are both the preachers 'dai' and mad'u 'the recipients', without any intervention by the researchers so that they are not influenced by the presence of researchers on observing and recording their language use. Thus, the oral data form concerns the typical use of language spoken form by dai within the frame of dialogical da'wah in the city of Surakarta. The language use in speech organized in a series of question and answer (Q\&Q) between the dai and mad'u, which focuses studying the directive type of speech acts use. Concerning the data sources, dakwah is language use in monologue form, the main data source not only the dialogic da'wah organized by Islamic organizations, but also those which organized by community groups taken place at houses or in the mosques. After conducting several observations, there were 14 dialogic da'wah locations, ie PCM Banjarsari, PCM Jebres, PCM Kota Bengawan, MTA Cabang Jebres 1, MTA Branch Jebres 2, MTA Binaan Pasar Kliwon, Majelis Asysifa, Pengajian Kelompok Haji Arofah 92, Islamic gathering or Pengajian Ibu-Ibu Annikmah, Masjid Alhikmah, Masjid Alfurqon, Masjid Alfajr, Rektorat UNS, 
and at the house of Prof. Dr. Moch. Fathoni, dr., Sp.JP (K).

After the data source is determined, the next step is data retrieval. Data obtained through the method of observation. This is undertaken without considering the researchers' involvemen, the typical use of observation method is the uninvolved conversation technique (Sudaryanto, 1988). This method is undertaken by listening to dialogical da'wah (lectures in typical Q \& A conversation between dai and mad'u) without being intervened by researchers. During the sessions, the researchers only act as an observer while listening carefully to the lectures or answers presented by the da'i or Islamic preacher, in addition to record the data. The recording technique assisted by digital camera use and $\mathrm{MP}_{3}$ recorder. Through digital cameras there can be obtained tangible audio and visual data. While $\mathrm{MP}_{3}$ optimally use to provide significant assistance to the researchers in producing the audio type of data. However, the audio data is emphasized rather than visual data at the data analysis section. The visual data is useful to help researchers interpreting the intent of audio data.

The basic theory used in analyzing this research data is the speech acts theory by Searle (1971). Speech acts is one of the sub-branches of Pragmatics, as Searle further explains (1971: 39) it is a minimal unit of linguistic communication. The directive speech acts model in this study refer to the Searle and Vanderveken's typology (1985: 198) among others; the acts of directing, asking, questioning, commanding, prohibiting ', permiting, suggesting, asking emphatically, warning, counseling, advising, pleading, and praying. In determining the various types of directive speech act reflected in the dialogical da'wah in the city of Surakarta, the typical device used concern the linguistic device (lingual markers) descibed by Yule (1996) who suggest the focuse of IFID (illocutionary force indicating devices). The IFID including the words order, the used verbs, intonation, or sentences mode used. In addition to the use of pragmatic concern on the contextual matter. The context accor- ding to Leech (1993) is the related aspects on both physical and social environment of a speech. Leech additionally emphasizes that context relates to a background knowledge shared by speakers and the speaking partners and this context helps the speaking partners interpreting the speaker's utterances.

Concerning the value of Javanese culture used when delivering speech acts directive, the author uses the language modesty formulated by Asim Gunarwan. Gunarwan (2000 and 2005) proposes the typical naming of politeness in the language interaction which he called the principle of harmony (Ind.kerukunan). The principle of harmony refers to the necessity of each individual in order to maintain a social balance (harmony). The essence of the principle of harmony is an attempt to avoid conflict. This principle is translated into four maxims, among others the maxim of kurmat ('honoring'), andhap asor ('modesty'), empan papan ('being aware of conditions'), and the maxim of tepa slilra ('tenggang rasa'). The maxim of kurmat requires the speaker to use the language in such a way that the speech partner knows that he is being respected in his place. The maxim of andhap asor suggests speakers to use language in such a way that the speaking partners will not interpret the speaker as arrogant. Meanwhile, the empan mapan maxim means the speakers are required to use the language according to their socially identified position within the community level and based on the acceptable contextual situation. The last is, the maxim of tepa slilra suggests a speaker in order not to use inappropriate language toward others. According Gunarwan, when the speech of a speaker adheres to the four maxims, it means he/she is still upholding the Javanese cultural values.

\section{RESULTS AND DISCUSSION}

After the data has been transcribed and classified, there are 9 acts of directive speech expressed by the da'i (-s) in their dialogic da'wah in Surakarta. The nine acts of speech are the act of commanding, asking, sug- 
gesting, confirming, questioning, inviting, permitting, warning, and praying. From the aforementioned types of directive speech acts, only three types of the directive speech acts are classified into face-threatening, i.e. the speech acts of commanding, suggesting, and warning. The three considering acts of speech acts are classified as the acts of threatening face because of the natural forces of the acts limiting the speaking partners' acts. Here is an explanation of each speech act.

\section{Speech act of Commanding}

The speech act of commanding s the act of uttering something that intend to the speaking partner(s) to do what the speaker says. To express the speech acts of commanding, one of the conditions which must be met is, the speaker should have authority or power over the speaking partners. In the dialogical da'wah in the city of Surakarta, the act was sent through four forms, namely the use of imperative mode (commanding sentence), this can be seen based on typical use of words like silakan / mangga, the expression of 'a must', the often find use of the imperative word like 'jangan' (prohibiting one to do something). In (1) the following data describe the use of imperative forms and the use of the word jangan to express the act of commanding.

(1) Dai : Ini terjadi nek ora ngerti gitu ndak no problem. Ini wong wis ngerti nggon gudang ya. Maka jangan kita itu jadi pemborong ilmu! Jadilah pemelihara!

Context: A dialogic da'wah organized by MTA (Majelis Tafsir Alquran) the Branch of Jebres 1 . The $D a{ }^{\prime} i$ is a 56 -year-old man. Meanwhile, the mad'u (community gathering) as the speaking partners are the adults between 25 years to 60 years-old. Dai as a speaker commanding the mad'u not to be a contractor of knowledge or science but as the sustainers of the knowledge.

In data (1) there were found two types of directive speech acts delivered through the utterances Maka jangan kita itu jadi pemborong ilmu! dan Jadilah pemelihara! Concerning the first utterances on the use of imperative word jangan, although the intended meaning out of this use is to command the speaking partners (listeners). While the second utterance is Jadilah pemelihara! (be the sustainer!) is categorized as the utterance which imply the act of commanding, the typical form of the utterance is imperative. Part of the interesting thing about the utterances are, there were found words mitigating the force on the speech utterances. On the first utterance, the speaker intentionally and inclusively used the pronoun word of kita 'we' at the time of commanding the recipients. This has an implication that imperative message may not only assume to address the recipients but also the speaker. On the second type of utterance, Jadilah pemelihara! (be the sustainer!), the speaker structurally use a particle -lah (in Bahasa Indonesia) to soften the imperative force of the utterance. This is quite different from the use of particle -lah if in case being omitted from the utterance. The assuming message could be a direct command to the recipients of discourse.

The other variables are speakers as the users of directive speech acts who are subsequently old. Hence the mad'u (recipients) are of various ages. If it is based on age, it seems the speaker shows his earnest respecting the mad'u by the plural noun of we ' $k i t a$ ' in addition to the use of particle-lah to mitigate the force in his utterance. Thus, there is an effort made by the da'i to observe the maxim of kurmat as an effort those normally underlying communicative manners among the Javanese people. Relying on the religiously determined status point of view, the speaker is categorized as much more superior among the other speaking participants. On the basis of such status, actually the $d a$ ' $i$ can convey these two utterances without using the two aforementioned devices, which is the use of pronoun 'we' kita and the particle of-lah. Just as an effort to respecting the mad'u (the discourse recipient), thus the direct force of an act of commanding is mitigated.

Another found forms concern the use of a compulsory statement as described in data (2) below. 
(2) Dai: ... Ini siapa yang taat pada Allah dan rasul-Nya, mau menunaikan hukum waris, nah itu surga. Ayat empat belas siapa yang gak mau, neraka. Itulah ancaman Allah kepada yang tidak mau menunaikan hukum waris. Maka kalau kita semuanya warga Muhammadiyah itu, ya mestinya harus taat kepada Allah dan rasul-Nya, ya harus!

Context: The dialogic da'wah took place in PCM (Pimpinan Cabang Muhammadiyah) "Chief of Muhammadiyah" Branch of Organization, Jebres. The da'i as a speaker of 58-year-old. Meanwhile, mad'u (the discourse recipients) as the speaking partners are of a branch manager and branch administrators aged between 30-60 years. Dai at that time told mad'u to be obedient to the Allah's command and His messenger.

In data (2) there were found speech act expressed through the utterances of "Maka kalau kita semuanya warga Muhammadiyah itu, ya mestinya harus taat kepada Allah dan rasul-Nya, ya harus!" In the speech, the commanding speech act expressed in a compulsory form of statement. The use of the word harus 'a must or compulsory' on the utterance speech. In pragmatic literature, the statement of a must/compulsory as well as the imperative mode is the realization of a direct speech acts. This means that both the speech meaning and purpose are quite the same so that the speaking partners can understand what is being said. However, the utterances are seemed to be softened through the word "kalau" and "kita" pronouns. Meanwhile, the use of the word kita or 'we' implies that the speakers show the similarity of Muhammadiyah community who must obey Allah and His Messenger.

The use of kalau 'if' and the pronoun kita 'our' imply that the dai is trying to respect the mad'u. As explained above, the use of both devices aims to soften the speech acts' continuity. However, in terms of age, the da'i is considered an old man, thus it could be culturally tolerated if expressing direct speech command. Moreover, the $d a{ }^{\prime} i$ is also a superior speaker. Only these two factors do not seem to affect the da'i expressing the direct speech acts. As a realization of honoring the mad'u, the use of pronoun kita 'we' at the time of expressing a commanding speech acts. The use of the word kalau 'if' it implies that the da'i attempts to observe the maxim of tepa slilra. In other words, from the perspective of Javanese norm and politeness, the $d a ' i$ is perceived to have observed the maxims of kurmat and tepa slilra.

The last use of form to convey speech acts of commanding is on the use of words mangga 'please or kindly'. In the following data (3) it is found the word use mangga to convey the speech acts of commanding.

(3) Dai: Mangga enten sing tanglet malih! 'Silakan ada yang bertanya lagi!'

Context: The dialogic da'wah took place at Al Furqon Mosque. The da'i as a 5o-year-old speaker. Thus, the mad'u are the Al-Furqon mosque of members aged between 20 to 60 years old. On that occasion, the da'i instructs with respect to the mad'u in order to asking for questions.

In the data (3) it is found the speech act of commanding expressed by a speaker in his utterance Mangga enten sing tanglet malih! 'Kindly ask any more questions!' By this utterance, the da'i clearly commands the mad'u to ask for questions. The interesting thing here is that the expressed utterances realized in krama form. In addition to observing the krama form, the speaker also used the word mangga. These as ilustrated in data (1) and (2), the krama conversational manners and the use of word mangga is intended to soften the ilocutionary force on the act of commanding.

In data ( 3 ) found the use of structural form of krama by da'i addressed to the mad'u. In addition to implying that dai adhere to the maxim of kurmat, the da'i would also like to show attitude of observing the andhap asor maxim. Despite the fact that the dai is a superior and older speaker, these two factors may not solely seem to affect Dai to directly express the speech of commanding. Moreover, on the data (3), other than observing the maxim of kurmat, additionally found the speaker observed the andhap asor maxim. This at least implicates 
the the da'i wishes to show a harmonious communicative behavior toward the mad'u (the discourse recipients) as has been the primary principle of Javanese people who at anywhere and anytime uphold the principle of living in harmonious (Gunarwan, 2001).

The Speech Acts of Suggesting

The speech acts of suggesting is an act expressed by a speaker to suggest the discourse recipients to do something. The suggesting act is expressed by $d a^{\prime} i$ considering that the message in suggestion form is important and consequentlybenefited the mad'u. On the dialogic da'wah discourse in Surakarta, there 5 typical speech acts patterns of suggestion, one is in imperative pattern, providing opts to the discourse recipients, and the impersonal pattern, the use of hedging form sebaiknya 'it is recommended', and the expressed message through clues. On the data (4) below, there were found the use of suggestion speech acts which realized through imperative forms.

(4) Dai: Nah, coba panggil, panggil yang baik! Kira-kira tenar lagi nggak ya? Lha dipanggil buruk tenar, kalo dipanggil gitu tenar lagi. Kalau tadi ya terjadi di kalangankalangan yang orang yang tidak ngaji ya ya itulah budaya mereka. Nah kita sebagai Islam yang baik-baik saja!

Context: The dialogic da'wah took place at the MTA Organization Brach of Jebres 2. The $d a^{\prime} i$ as a speaker of 61 years old. Whereas, the mad'u (the discourse recipients) are students of university aged between 19-23 years old. At the time, the da'i suggest the questioner and mad'u in order to call someone with the best of their names.

On the data (4), the da'i expresses two speech acts in the utterance Nah, coba panggil, panggil yang baik! and the utterance Nah kita sebagai Islam yang baik-baik saja! Even though the aforementioned utterances were expressed in imperative forms, the da'il would seem to lessen the illocutionary force of his suggestion. Particularly, the use of imperative word coba 'just try' and inclusive pronoun kita 'we' play a great role in mittigating the discursive force of the suggesting utterances. On the first utterace, the da'i prefers the use of word coba 'just try' as a typical use of hedging. The use of hedging coba, it optimally lessens the directness of the speaker's expressed intents. While the inclusive pronoun use of kita or 'we' implies a symmetrical relationship between the speaker or da'u and the message recipients or mad'u in terms of practicing religious orders. In other words, there is nothing special treatment and specific order that distinguish between the da'i and his mad'u in religious affairs.

Concerning the typical use of linguistic tools expressed in above, it shows that the $d a ' i$ earnestly observe polite language although he might realize that the structural sentence is in imperative form. In addition to that, by mitigating the imperative sentence on the speech acts of suggesting above implies that the da'i seems to show his honor towards the mad'u. In the other words, the $d a^{\prime} i$ attempts to observe the maxim of kurmat 'honoring' as the manifestation of honoring form to the discourse recipients ( $m a ' d u$ ) although he is older in age from the mad'u and is superior in both religious and social matters.

The other forms of discourse structure use by the $d a$ ' $i$ at the time expressing the speech act of suggestion, is to provide optionality. On the data (5) below there were found the structural discourse of the da'i expression giving option to the mad'u.

(5) Dai: Pemerintah itu diikuti kalau sesuai dengan ajaran kita. Kalau dak sesuai ya jangan. Seumpamanya pengertian zina. Ada anak laki-laki berzina dengan anak perempuan....

Context: The dialogic da'wah took place at the PCM Jebres. The da'i as a speaker of 58 years old. In that context, the mad'u who engage this activity is the branch administrators and the administrators of Jebres sub-district, among others the adults between the ages of $30-60$ years old. At that time the speaker expresses his advice to the questioners and mad'u to following the rules of government in line with the teachings of Islam.

On data (5), the da'i expresses speech acts of suggestion, which is classified into 
two types of utteances, among others; (i) Pemerintah itu diikuti kalau sesuai dengan ajaran kita and (ii) Kalau dak sesuai ya jangan. The two utterances were expressed in optional structural form, as it is identified the the use of word kalau 'if, in case', etc.). The two aforementioned utterances were expressed with kalau, which implies the da'i attempts to mitigate his utterance force and create an indirect instructional discourse through applying the so called if-clause in his speech acts of suggestion.

In addition to being intentionally mitigating the direct force of utterances, it seems that the $d a^{\prime} i$ also inclined toward using the word of kalau for other intended aims. The use of such structure links to the observation of tepa slilra maxim.

The next structural form is used at the time of expressing the speech act of suggestion, which is through impersonality. The impersonality concerns expressing intended messages in passive form of structure, indirect address of message to person or someone. Below is the expression of speech acts of suggestion in impersonal pattern of sentences.

(6) Dai: Maka di rumah diajak belajar kelompok. "Yo Pak belajar kelompok yo Pak yo"!

Context: The dialogic da'wah took place at MTA Binaan Pasar Kliwon. The da'i as a speaker of 58 years old. While the mad'u or discourse recipients of this sermon is people of MTA community of various ages between $20-60$ years old. In this occation, the da'i gave a suggestion to the questioner in order to gain knowledge of religion through congregation.

On the data (6) the da'i expresses the speech act of suggestion described in utterance Maka di rumah diajak belajar kelompok. This utterance is expressed by da'i in impersonal pattern of language identified by the use of passie form on the verb diajak 'being invited'. This structural patter of use describes an attempt of the da'i in order that his utterances seem indirectly suggesting the addressee. In other words, the da'i mitigates the direct expression of a suggestion speech act.

Other than the reasons of mitigating the direct force of utteraces, the use of impersonal pattern implies that the da'i would really like to honor the mad'u. Although the da'i is older in terms of age, however, such a factor shall never be an excuse for him to not honoring the mad'u. In other words, on data (6) it is interpreted tha the speaker observes the maxim of kurmat.

The forth language pattern used by $d a$ 'i to expresses the speech act of suggestion is through hedging use. Below data describes the speech act of suggestion in hedging form.

(7) Dai: Kalau edan itu ya, itu pasti orangorang Sebaiknya kita menghindari panggilan-panggilan buruk!

Context: This dialogic da'wah was held at MTA Organization Brach Jebres 2. The da'i as a speaker of 61 years old. While the mad'u or discourse recipients are students of university aged between 19 to 23 years old. At that time the $d a^{\prime} i$ provide suggestion to a questioner and mad'u in order to avoiding calling people with bad or unrecomended names.

On data (7) there were found the expressed speech acts of suggestion from the utterances Sebaiknya kita menghindari panggilan-panggilan buruk! By the use of sebaiknya it is better for us/suggestive form', the illocutionary force of the inderect speech act is mitigated. In addition to other impressed attitude of the speaker, is the da' $i$ attempts to produce non-enforcing language expressions. Other mitigations used in the interactions between the da'i and mad'u on such utterances on data (7) are he use of inclusive pronoun kita or 'we'. The pronoun kita on data (7) implies an intention that the $d a ' i$ and mad'u share the same ideas of avoiding the calling of people with unrecomended names.

In addition to mitigating the direct force of utterance, the use of a suggestive word "sebaiknya" (it is better for) also implies that in order that expressed utterance would be interpreted as more polite. Thus, it is shown here that the da'i earnestly try to honor the 
mad'u as his speaking counterpart. Therefore, the inference for the the hedging use on data (7) it is indicated that the da'i observed the maxim of kurmat.

The last linguistic structural pattern of speech acts by the da'i, it is strategically expressed through making it seems ambigous (eleptical). In other words, the da'i expresses the indirect type of speech acts that is intentionally expressed to suggest the recipients. Below data indicates the indirect type of speech act to suggest the speaking partners.

(8) Dai: Padu. Sedikit aja hmm ya, "Mari tahajud sayang!" Nggih to? 'Ya kan?'

Context: This dialogic da'wah takes place at the MTA Binaan Pasar Kliwon. The da'i as speaker of 58 years old. While the mad'u the discourse recipients are among the members community of MTA Organization aged between $20-60$ years old. At the time, the da'i expressed suggestion to the questioner inviting them to perform tahajud prayer when a husband and the wife is in turbulance or in a coflict.

On the data (8) the da'i expresses the speech act of suggestion on the utterance Sedikit aja hmm ya, "Mari tahajud sayang!" Nggih to? 'Ya kan?' The typical utterance is in imperative form despite it is mitigated. The utterance seems to inform the mad'u. However, in additon to inform the recipients, this implies suggestion in order that the husband performs tahajud prayer at the time he was in conflict with his wife. This structural form implies a subtle clue since the discourse recipients have not found the imperative form that such utterance reflect the speech of act suggestion. The speaking partners (recipients), however, share the same undertanding in interpreting the data (8) in case it is referred to the existing context.

The ambiguous pattern, especially through using subtle clues implies that the da'i suggests mad'u by considering to what extent the face-threatening act would affect the listeners. In this context, it seems that the da'i perceived the mad'u's face would be threatened in case he is expressing a direct form of suggestion; therefore, he turned the expression into ambigous (eleptical). In addition to decreasing the directness degree of such utterance to the mad'u, this sort of form enhances the politeness degree. For that reason, the ambigous pattern (subtle clues) shows that the attempts made by the $d a^{\prime} i$ in observing both the maxims of kurmat and tepa slilra.

\section{The Speech Acts of Warning}

The speech act of warning is an act containing a warning against the speaking partners in order to do things intended by the speaker. On the dialogic da'wah in the City of Surakarta, the speech act of warning expressed in a strong and subtle clues partterns. Below is the utterance showing the strong clues pattern.

(9) Dai: ... Wis pokoke aku ngetokke. Nggo mesjid nggo apa terserah. Kita nggak ngurus itu. Lha ini hati-hati!

Context: This dialogic da'wah held at PCM Kota Bengawan. The da'i as a speaker aged 66 years old. While the mad'u is the brach administrators and branch administrator of Muhammadiyah Organization in the Pasar Kliwon regency. In that occasion, the da'i warned the mad'u (discourse recipients) in order to be aware of issuing for zakat 'alms'

On data (9) the utterance Lha ini hatihati! is categorized into speech act of warning. Out of that contextual utterance, it is inded the speech act of warning. This is identifiable from the word use hati-hati 'beware, careful etc. This type of word is normally used at the time a speaker warn the speaking partner about something hazardous.

This type of use implies that the speech act of warning has a greater degree of face threatening impacts. Consequently, the $d a^{\prime} i$ eventually opt to use this utterance in order to avoiding the mad'u to lose their face. Additionalluy, the use of a strong clues indicate the da'i intend to address his message politely. Observing this case from the Javanese harmonious principle, it seems that the da'i observed the maxim of tepa slit- 
ra. By using a typical strong of clue utterances, the dai intentionally would never like to threaten his mad'u's face (personal image) vise versa.

Another pattern, used by the dai at the time expressing specch acts of suggesting is a subtle clue form. This pattern shows that the speaker observed the subtle clue expression.

(10) Dai: ... Kalau sekarang banyak HP yang bisa langsung connect internet. Jadi sarana untuk maksiat itu sangat mudah kita miliki, sangat mudah kita kerjakan. Menyendiri itu berbahaya sekali.

Context: The dialogic da'wah at MTA Brach of Jebres 2. The da'i as the speaker aged 61 years old. While the mad'u (the discourse recipients) the communicative members are students of university aged between 19-23 years old. At that time the $d a{ }^{\prime} i$ warned both the questioner and mad'u in order not to be often daydreaming and lonely.

On data (10) it is found the speech act of suggestion expressed by da'i on the utterance Menyendiri itu berbahaya sekali. On the basis of such utterance, there were not found any linguistic device classifiying this into the speech act of suggestion. However, it is contextual bond. The ilocutionary meanings of the utterance will be work only then it is interpreted from the contextual situation. This is characteritically of an utterance which is expressed through subtle clues.

The use of subtle clues utterances as discussed above implies a number of things. First, this type of communicative behavior is primarily used due to the speaker's high concern for the audiences' face losing in expressing utterances which contain the speech acts of warning. That's is why the speaker/da' $i$ is necessarily soften/mitigate the ilocutionary forces of expressing the direct meaning of utterance and as part of his concern minimazing the threatening degree to the speaking partners' face (mad'u). Additionally, the inderect communicative form (expressing subtle clues) shows that the da'i attempts to observe the maxim of tepa slilra. Further inference towards the speaker ob- serving this maxim, it lays on a reason that the $d a{ }^{\prime} i$ intentionally avoids threatening the mad'u's face.

\section{CONCLUSION}

Language is one of the highly pivotal part of a culture. Thus, one's linguistic attitude within socitety is of course influenced by the social cultural values of the respected community. This is also happened regarding the mad'u's question on dialogic da'wah in the city of Surakarta. Some of the potentionally threatening utterances to mad'u's face should never be randomly expressed.

Departing from the results of the discussion, the most potential utterances threatening the mad'u's face within the dialogic da'wah discourse is utterances that reflect the speech acts of commanding, suggesting, and the act of warning. To decrease the level of face threatening to the mad'u in expressing the three aforementioned speech acts types, it is indicated that the da'i use a number of linguistic tools, such as the use of word kalau 'in case' or 'if', and the word sebaiknya 'it is better', the pronoun use of kita (inclusive), the particle of -lah, the use of passive form (impersonal), the use of clues, both the strong and subtle one.

In addition to lessening the possibility of face threatening to the mad'u and mitigating the direct force of the utterances use, the use of various linguistic tools were influenced by the accepted Javanese cultural values practiced by the people living in Surakarta. The use of such various tools, it proves that the dai' observe the maxim of harmony to decrease any occuring conflict, in addition to maintaining the social balance. Such observed patterns are realized by the $d a ' i$ or religious preacher, in this domain, through expressions adhering to the communicative principle of kurmat, andhap asor, and tepa slilra. Even though the da'has his own position in society and religious matters, such factors may not be absolutely influenced the $d a^{\prime} i$ to breaking the principle of harmony. Despite the fact that the harmonious principle has been constantly upheld by the da'i, in addition he might be 
older than the discourse recipients (mad'u). This phenomenon implies that the language attitude of $d a^{\prime} i$ is completely linked to the Javanese cultural atmosphere which prefers sustaining the world balance and avoiding of the social conflict possibility.

\section{REFERENCES}

Austin, J. L., 1962. How to do things with words. Oxford University Press, Oxford Mass.Brown, P. and Stephen L., 1987. Politeness Some Universal in Language Usage. Cambridge University Press, Cambridge.Eelen, G., 2001. A Critique of Politeness Theories. St Jerome Publishing, Manchester

Fraser, B., 1990. "Perspectives on Politeness" dalam Shoshana Blum-Kulka and Gabriele Kasper Journal of Pragmatics, 14, pp. $219-236$.

Fortanet, I., 2003. 'I think: Opinion, Uncertainity or Politeness in Academic Spoken English' Artikel, Universitat Jaume. Retrieved from: hattp://lingo.lancs.ac.uk/devoted to/corpora/ corpora.htm

Gunarwan, A., 2000. "Tindak Tutur Melarang di Kalangan Dua Kelompok Etnis Indonesia: Ke Arah Kajian Etnopragmatik" cited in PELLBA 13. Unika Atma Jaya, Jakarta.Gunarwan, A., 2005. "Beberapa Prinsip dalam Komunikasi Verbal: Tinjauan Sosiolinguistik dan Pragmatik" dalam Bahasa, Sastra, dan Pengajarannya. Penerbit Universitas Sanata Dharma, Yogya-
karta.Leech, G., 1983. The Principles of Pragmatics. Longman Group Limited, New York. Locher, M.A., 2015. 'Interpersonal pragmatics and its link to (im) politeness research'. Journal of Pragmatics, 86, pp. 5-10.

Moliong, L.J., 2011. Metode Penelitian Kualitatif edisi revisi. Rosda, Bandung.Riekkinen, N., 2009. This is not criticism, but...Softening Criticism: The Use of Lexical Hedges in Academic Spoken Interaction. Postgraduate Thesis. University of Helsinki.

Searle, J.R., 1971. The Philosophy of Language. Oxford University Press, New York.Searle, J.R., 1979. "A Taxonomy of Illocutionary Acts" dalam A.P. Martinich (ed). 1996. The Philosophy of Language. Oxford University Press.6, Oxford. Searle, J.R. dan Vanderveken, D., 1985. Foundation of Illocutionary Logic. Cambridge University Press, Cambridge.Sosiowati, I G. A., 2013. Kesantunan Bahasa Politisi Dalam Talk Show di Metro TV. Disertasi, Program Doktor Program Studi Linguistik.

Sudaryanto, 1988. Metode Linguistik Bagian Pertama ke Arah Memahami Metode Linguistik. Gadjah Mada University Press, Yogyakarta.Sugiyono, 2011. Metode Penelitian Kombinasi (Mixed Methods). Alfabeta, Bandung.Yule, G., 1996. Pragmatics. Oxford University Press, Oxford. Žegarac, V., 2008. "Culture and Communication” dalam Spencer-Oatey, Helen (ed). Culturally Speaking Culture, Communication, Politeness Theory. Second edition. Continuum International Publishing Group. pp. 48 - 70. 